\section{Dialogismo: as vozes em notícias de um estupro coletivo}

Dialogism: the voices in news of a gang rape

Rosângela LONGHI (UCS)

rosangelalonghi@gmail.com

Luciane Todeschini FERREIRA (UCS) lucianetodeschini@gmail.com

Recebido em: 04 de nov. de 2017. Aceito em: 14 de maio de 2018.

\section{0}

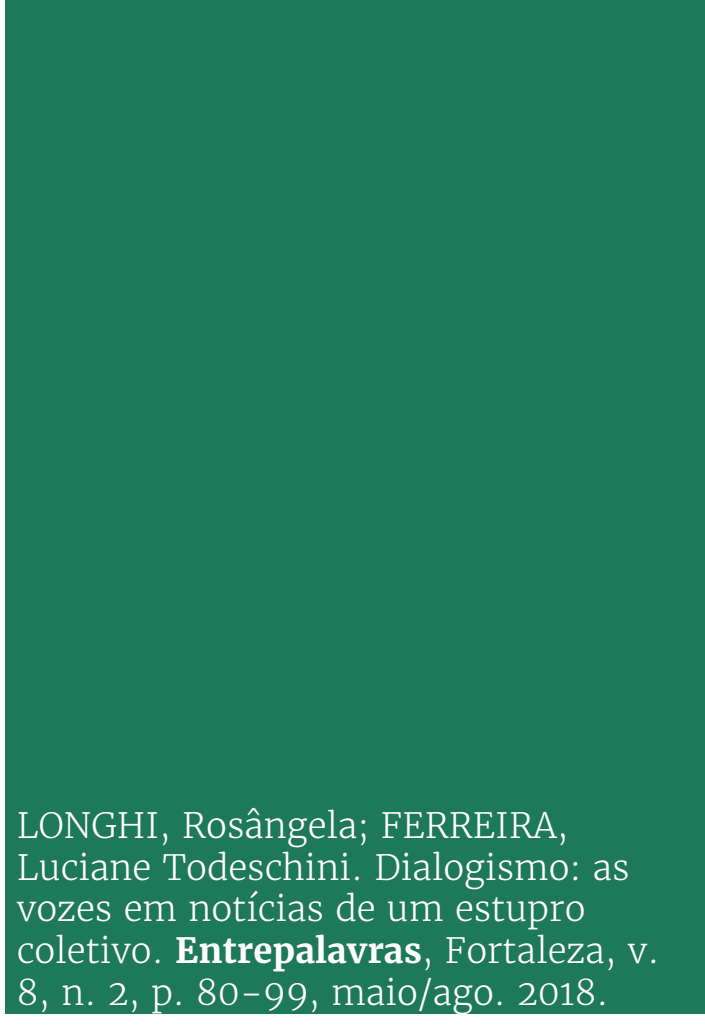

Resumo: Este artigo tem como objetivo identificar as diferentes vozes que se organizam no discurso jornalístico e como o dialogismo aparece no gênero notícia, apontando para a responsividade, tal como postula Bakhtin (2011). Para o filósofo, o dialogismo é o princípio constitutivo da linguagem, e, nesse sentido, o discurso não é individual e mantém relação com outros discursos, sendo sempre responsivo. A partir dessa fundamentação, foram selecionadas cinco notícias online, publicadas em diferentes portais, no dia 26 de maio de 2016, referentes ao estupro coletivo de uma jovem de 16 anos na cidade do Rio de Janeiro. O assunto foi amplamente abordado na mídia e gerou comoção nacional. Metodologicamente, a partir dos pressupostos bakhtinianos, esse corpus identifica quais são as vozes presentes e como a enunciação jornalística dialoga com elas. Portanto, todo texto sempre responde a uma série de vozes, marcadas ou não no discurso.

Palavras-chave: Dialogismo. Polifonia. Notícias de um estupro. 
Abstract: This paper aims at identifying the various voices that are set up throughout journalistic discourse and how the dialogism appears in the genre news, pointing out, as stated by Bakhtin (2011), to the responsivity. According to the philosopher, dialogism is the constitutive principle of language. In this regard, speech is not secluded and bears relation to other speeches. From such theoretical framework, this paper examines five online news pertaining to the gang rape of a 16-year-old girl in the city of Rio de Janeiro. Published in different web portals on May 26th, 2016, the news were widely divulged by the media and caused national stir. When it comes to methodology, by taking Bakhtin's assumptions into account, this paper identifies the voices and how the journalistic enunciation dialogues with them. Therefore, every text always responds to a number of voices, whether they are signaled or not in discourse.

Keywords: Dialogism. Polyphony. News of a rape.

\section{Introdução}

A linguagem constitui o ser humano e é por meio das diferentes linguagens que os sujeitos interagem entre si, com o mundo, criando e recriando significações que são invariavelmente circunscritas no tempo e no espaço. Se o homem é linguagem, há de se refletir sobre as distintas formas que ela se apresenta e mais, há de se refletir sobre os efeitos de sentidos que produz.

Reflexões sobre a linguagem são antigas e remontam a estudos no século IV a.C por meio de textos sagrados do povo hindu. Os gregos Platão e Aristóteles garantiram ainda maior destaque à temática, ao analisar a relação entre a palavra e o significado. Enquanto o primeiro tratou a questão na obra Crátilo, investigando se a compreensão de determinado signo era convencional ou se havia uma relação natural, o segundo avançou os estudos com foco na estrutura linguística, ao analisar a frase, o discurso e as categorias gramaticais, pois, para ele, esse era o caminho de se chegar ao conhecimento das estruturas e da lógica da realidade (PETTER, 2010).

Pensar e refletir sobre como tudo é organizado pela linguagem, portanto, tem sido uma atividade ininterrupta. No mundo moderno, as reflexões de Ferdinand de Saussure, transcritas e publicadas por seus alunos no início do século XX, representaram um marco para a definição da linguagem, língua e fala e, consequentemente, permitiram tratar a linguística como ciência. Conforme os estudos do filósofo suíço, a língua é abstrata e depende da coletividade, enquanto a fala, parte integrante da linguagem, é concreta e individual (SAUSSURE, 2012).

É a partir dessa nova ciência que os estudos sobre a linguagem ganham aprofundamento por meio de uma série de estudiosos, de várias escolas linguísticas e movimentos literários. 
V. $8(2)$

80-99

mai/ago 2018

O entendimento de linguagem fortemente relacionado ao social foi sustentado por Mikhail Bakhtin1, ao assegurar como objeto de estudo que a linguagem determina o sujeito e também o empodera nas ações. O filósofo russo e teórico das questões literárias tomou o enunciado como único, pois ocorre em determinado contexto. Assim, para ele, essa singularidade decorre das relações dialógicas, visto que todo enunciado se relaciona com outros enunciados.

O enunciado em sua plenitude é enformado como tal pelos elementos extralinguísticos (dialógicos), está ligado a outros enunciados. Esses elementos extralinguísticos (dialógicos) penetram o enunciado também por dentro (BAKHTIN, 2011, p. 313).

Esse caráter dialógico da linguagem aponta que toda fala é endereçada a outro e que esse outro também, entrelaçado aos fios ideológicos, responde a alguém, sendo, portanto, de natureza responsiva. "Cada enunciado é pleno de ecos e reverberações de outros enunciados, com os quais se relaciona pela comunhão da esfera da comunicação verbal" (BAKHTIN, 2011, p. 297).

Bakhtin trata o texto, seja ele escrito ou oral, como dado primário da linguística, da filologia e da literatura. Para ele, é apenas pelo texto que existe objeto de pesquisa e pensamento, ou seja, uma intenção comunicativa transmitida pelo sujeito/autor. O texto é o centro de toda a investigação sobre o homem e a materialização do enunciado. (BAKHTIN, 2011). "Só o enunciado tem relação imediata com a realidade e com a pessoa viva falante (o sujeito) [...] Só o enunciado pode ser verdadeiro (ou não verdadeiro), correto (falso), belo, justo, etc." (BAKHTIN, 2011, p. 328, grifo do original).

Isso posto, no presente artigo, há uma seleção de notícias que tratam de um estupro coletivo com o objetivo de identificar se há a articulação de diferentes vozes e como o dialogismo se constitui por meio do gênero notícia. Esse gênero foi selecionado por ser amplamente conhecido, fazendo parte do cotidiano do homem, que busca conhecer, e entender, as circunstâncias que o cercam. Cinco portais nacionais de notícias que divulgaram o estupro coletivo de uma jovem de 16 anos, no

\footnotetext{
${ }^{1}$ Mikhail Bakhtin foi um filósofo russo (1895-1975) e um dos pensadores de uma rede de profissionais, chamado Círculo de Bakhtin, preocupado com as formas de estudar linguagem, literatura e arte. Nessa rede, estavam também o linguista Valentin Voloshinov (1895-1936) e o teórico literário Pavel Medvedev (1891-1938). Até hoje há controvérsias quanto a autoria de alguns dos livros que pode ser atribuída apenas a Bakhtin ou ao Círculo como um todo.
} 
Rio de Janeiro, em maio de 2016, serão utilizados como corpus. São eles: CBN, Diário do Nordeste, O Globo, Veja e Zero Hora. O fato gerou comoção nacional após um vídeo ser compartilhado, pelos próprios envolvidos, em mídias sociais, o que motivou, inclusive, a campanha 'Fim da cultura do estupro'. A iniciativa mobilizou centenas de mulheres de diferentes perfis para chamar a atenção contra esse tipo de violência, o que permitiu trazer à tona uma série de pontos de vistas e vozes a esse respeito.

\section{Notícia: um gênero sempre atual}

Factualidade, ineditismo, proximidade, verdade e o interesse público são características que permitem transformar um acontecimento em notícia. Erbolato (1991, p. 52) esclarece que "as notícias são comunicações sobre fatos novos que surgem na luta pela existência do indivíduo e da própria sociedade". Já Lage (2001, p. 54) define notícia "como o relato de uma série de fatos a partir do fato mais importante, e este, de seu aspecto mais importante". Nesse ponto, a palavra "importante" é acompanhada de muita subjetividade, assim como a seleção de qualquer fato, visto que um acontecimento pode receber importância de uma pessoa e de outra não. Cabe ao jornalista pauteiro, repórter ou editor - a missão de definir o que publicar entre as centenas de informações que chegam diariamente à redação por meio de fontes oficiais públicas ou privadas, de agências de notícias e mesmo de sugestões ou denúncias dos próprios cidadãos.

A notícia pode comover, motivar revolta ou conformismo, agredir ou gratificar alguns de seus consumidores. Esses efeitos são apreciados e muitas vezes exagerados por quem se ocupa de política de comunicação ou de psicologia social. Trata-se de um problema para o mecanismo de poder em que o veículo está inserido ou, na prática, para os gatekeepers, aqueles que decidem o que vai ou não ser publicado. Quem escreve a notícia tem postura ética distinta: sua preocupação é saber se a informação tem importância ou desperta interesse bastante para ser publicada e como ressaltar essa importância ou interesse mantendo a conformidade com os fatos (LAGE, 2006, p. 26).

Em disciplinas do curso de Jornalismo, docentes apresentam modelos de maneira que o aluno consiga distinguir o que pode ou não ser notícia. Um dos exemplos mais usuais, trata-se do exemplo de que se um cachorro morder um homem não será notícia, porém, se um homem morder um cachorro isso será notícia pelo fato de ser uma situação inusitada. 
v. $8(2)$

80-99

mai/ago 2018
Para Rossi (1994), a regra é que toda notícia traga as seis perguntas principais do jornalismo (Quem? Quê? Quando? Onde? Por quê? Como?), porém o que acontece com frequência é que alguma das indagações apresentará importância distinta conforme a notícia. Particularmente, para ele, o porquê é a questão central e merece destaque, em especial nos veículos de comunicação que não possuem a agilidade, no caso o jornal impresso. "O porquê de um determinado fato envolve uma investigação profunda sobre seus antecedentes e consequências e uma razoável soma de conhecimentos sobre o tema que está sendo tratado" (ROSSI, 1994, p. 35).

A exemplo do que defendia Bakhtin (2011), quanto à riqueza e diversidade de gêneros, que crescem e se diferenciam à medida que se desenvolvem e se complexificam num determinado campo, com o advento da internet as notícias ganharam um novo espaço de propagação: os portais. A partir da década de 1990, o jornalismo online surgiu no Brasil como forte concorrente dos impressos, garantindo ainda maior velocidade às notícias, seja pelos meios diretos ou indiretos de informações. Portanto, ao trazer as definições de Bakhtin (1997) para o atual momento, pode-se constatar que os meios diretos são os portais que divulgam notícias com foco no leitor, enquanto os indiretos são as agências de notícias, cujo público-alvo são os veículos de comunicação.

No entanto, fica evidente que na atualidade, com o fácil acesso às notícias online, as agências acabaram perdendo espaço para os mais diversos veículos que trabalham com a informação da mídia eletrônica. Em se tratando de gênero digital, Machado (2001) aponta que esse conceito se dissemina em redes de interações. "Texto, imagem, movimento, som, tudo pode ser digitalizado e ganhar a estruturalidade de um enunciado concreto, ainda que seja realidade virtual" (MACHADO, 2001, p. 9).

Ao defender que o uso da língua ocorre em forma de enunciados, Bakhtin (2011) buscou uni-los de maneira que se adaptassem dentro de três condições indissociáveis e estabilizadas da comunicação discursiva: construção composicional, conteúdo temático e estilo. Essa estrutura, o filósofo russo classificou de gêneros, pertencendo a determinados campos com características próprias. Sendo assim, dividiu em gênero primário (identificado também como simples por ter origem da conversa diária ou de cartas pessoais) e secundário (apontado como composto por emergir de acordo com condições culturais mais desenvolvidas e organizadas como o romance e a linguagem científica, permitindo a 
incorporação do gênero primário). "Evidentemente, cada enunciado particular é individual, mas cada campo de utilização da língua elabora seus tipos relativamente estáveis de enunciados, os quais denominamos gêneros do discurso" (BAKHTIN, 2011, p. 262, grifo do original).

Logo, a notícia é caracterizada como um gênero secundário, com base nas reflexões bakhtinianas, com a incorporação de diálogos primários, ou seja, a coleta deinformações, comoasfontes, transformados, na sequência. Isso aponta para o dialogismo. Cabe ressaltar, porém, que a notícia, mesmo sendo um gênero "relativamente estável" (BAKHTIN, 2011), também comporta variações, o que pode ser visto nas notícias publicadas em portais. Como bem aponta Fiorin (2016, p.76), "O gênero une estabilidade e instabilidade, permanência e mudança".

Partindo-se do pressuposto de que a linguagem é construída na interação e de que há diferentes vozes que atuam em um discurso, as notícias são exemplos do quanto há em uma relação do eu com o outro, de respostas a enunciados, mesmo que não seja face a face, que concordam ou discordam, deixando evidente o dialogismo e a ideologia de quem seleciona, escreve e divulga determinado fato.

\section{Quantos falam, quando lemos uma notícia? A questão do dialogismo}

Por dialogismo, Bakhtin (2011) entende que não há palavra sem dono, mas um trio, pois além do autor/falante e do leitor/ouvinte, há vozes que estão na palavra encontrada anteriormente pelo autor.

De acordo com Tezza (1988, p. 55),

Nossas palavras não são 'nossas' apenas; elas nascem, vivem e morrem na fronteira do nosso mundo e do mundo alheio; elas são respostas explícitas ou implícitas às palavras do outro, elas só se iluminam no poderoso pano de fundo das mil vozes que nos rodeiam.

Foi na obra Problemas da poética de Dostoiévski que Bakhtin, ao identificar no romance diferentes vozes das personagens, elabora suas noções de dialogismo e de polifonia, essa última caracterizada por um dialogismo explícito, conceitos que reforçam o caráter responsivo do enunciado.

Bakhtin (2011, p. 271) defende que

Toda compreensão da fala viva, do enunciado vivo é de natureza ativamente responsiva (embora o grau desse ativismo seja bastante diverso); toda compreensão é prenhe de respostas, e nessa ou naquela forma a gera obrigatoriamente: o ouvinte se 
V. $8(2)$

80-99

mai/ago 2018 torna falante. A compreensão passiva do significado do discurso ouvido é apenas um momento abstrato da compreensão ativamente responsiva real e plena, que se atualiza na subsequente resposta em voz real alta.

Fiorin (2016, p. 22), com base nos pressupostos bakhtinianos, aponta que o enunciador é rodeado de discursos e, inevitavelmente, se utiliza do discurso do outro. Portanto, o discurso não é individual, mas construído nas relações com outros discursos. "[...] toda palavra dialoga com outras palavras, constitui-se a partir de outras palavras, está rodeada de outras palavras". Fiorin (2016) ressalta que um enunciado está realizado quando consente uma resposta do outro. Sendo assim, é peculiar do enunciado que ele não exista fora das relações dialógicas e polifônicas.

E isso não é diferente quando se reflete sobre o gênero notícia, pois embora ela se organize dentro de uma estrutura "relativamente estável" (BAKHTIN, 2011) também comporta singularidades. As vozes dissonantes, ou não, que compõem uma notícia e os tensionamentos existentes, muitas vezes, de forma explícita, mas em outras de forma implícita, são reveladoras da forma de a linguagem se constituir. Apesar de apresentar um enunciador, nesse caso o jornalista, a notícia demanda informações de outros interlocutores, portanto, o conceito de dialogismo, tratado por Bakhtin, revela que a notícia é inevitavelmente dialógica e também polifônica.

Bezerra (2005, p. 194) define polifonia como "a posição do autor como regente do grande coro de vozes que participam do processo dialógico". Quanto à polifonia, Bezerra aponta que ela é marcada pela interação, pela multiplicidade e independência de vozes.

\footnotetext{
Essas vozes e consciências não são objeto do discurso do autor, são sujeitos de seus próprios discursos. A consciência da personagem é a consciência do outro, não se objetifica, não se torna objeto da consciência do autor, não se fecha, está sempre aberta à interação com minha e com outras consciências e só nessa interação revela e mantém sua individualidade (BEZERRA, 2005, p. 194-195).
}

Em Marxismo e filosofia da linguagem, Bakhtin (1997) indica três formas de inserir o discurso do outro no enunciado, o direto, o indireto e o indireto livre, esse último uma variante do indireto. Segundo o filósofo, o primeiro é a transmissão fiel, palavra por palavra da enunciação, enquanto o segundo permite ao narrador integrar a voz da personagem à sua e, por fim o terceiro cujo contexto narrativo comenta e expõe o discurso citado. 
Fica evidente, por meio das noções de Bakhtin, que um discurso pode apresentar uma pluralidade de vozes, ou seja, as referências estão presentes nos enunciados ou em suas entrelinhas. Transpondo essas condições para o texto jornalístico, verifica-se que a polifonia está muito presente na notícia, visto a imprescindível necessidade das fontes, do leitor. A notícia não é construída apenas pelo jornalista, responsável por estruturar e narrar o fato, mas é incorporada por um ou vários outros pontos de vista, implícitos e explícitos no texto ou fora dele como é o caso de situações já experienciadas ou mesmo pré-conceitos.

\section{Metodologia}

Neste artigo, utiliza-se o conceito de dialogismo, proposto por Bakhtin, para apresentar as diferentes vozes que ecoam no gênero notícia. Um caso de estupro coletivo a uma jovem de 16 anos, na cidade do Rio de Janeiro, ocorreu no dia 21 de maio de 2016, porém ganhou repercussão nacional a partir do dia 26 de maio, quando a vítima realizou exames em um hospital da cidade e apresentou-se para depor na delegacia, acompanhada de familiares.

Talvez, o fato não tivesse ganho tamanha abrangência se a jovem tivesse sido violentada por um e não por 33 homens, como ela afirma, e se também os casos de violência contra a mulher não tivessem aumentado significativamente nos últimos anos, como aponta a Organização Mundial da Saúde (OMS), fato que posiciona o Brasil como quinto maior do mundo em taxa de feminicídio (ONU, 2017).

O estupro em questão deixa clara a ideia da factualidade, ao ter gerado visibilidade na mídia nacional, por meio de jornais, revistas, emissoras de rádio e televisão e portais de notícias. Muitos desses veículos acabaram sendo difusores de informação para outros veículos, ou seja, as agências não foram a fonte primeira de informação no corpus utilizado, com exceção da imagem que aparece em três dos cinco portais analisados, cujo crédito é atribuído a Gabriel de Paiva, da Agência 0 Globo.

De Norte a Sul do país, o estupro ganhou imediatamente as manchetes de portais de notícias, gerando a troca de informações entre os próprios meios diretos. O fato, portanto, alcançou abrangência nacional.

Para fins de pesquisa, foram analisadas cinco notícias de portais nacionais de comunicação online de um total de 50 encontradas, 
V. $8(2)$

80-99

mai/ago 2018 representando $10 \%$ do total. Os portais de veículos a serem analisados são: CBN, Diário do Nordeste, O Globo, Veja e Zero Hora. Importante ressaltar que os mesmos veículos analisados também são encontrados nas mídias tradicionais, ou seja, são jornais e revista impressos e emissora de rádio.

A escolha desses veículos aconteceu com o intuito de mostrar a diversidade de mídias em portais online (jornal, revista e rádio). Essa versatilidade do meio digital faz com que veículos sirvam de fonte para a construção de notícias a outros veículos que, sob um outro ponto de vista, reorganizam a informação e geram seus próprios efeitos de sentido. Além disso, é possível observar como a recepção de uma mesma notícia repercute nas diferentes regiões, no Rio Grande do Sul, São Paulo, Rio de Janeiro e Ceará, e culturas.

$\mathrm{Na}$ análise do corpus, são apresentados ao longo do artigo apenas os títulos e alguns trechos, com o intuito justamente de apontar a produção de sentidos e os tensionamentos provocados por elas.

\section{Análise}

Família queria que jovem estuprada fizesse tratamento para dependência química (CBN, 2016 [grifo nosso]).

O título, em terceira pessoa, revela uma tentativa de neutralidade, o que, não raro, é visto como uma das características do gênero notícia. Nesse ponto, Lage (1997, p. 38) explica que a comunicação jornalística trata de temas que estão extrínsecos tanto ao emissor quanto ao receptor. "Isso impõe o uso quase obrigatório da terceira pessoa". Para Fiorin (2016), relatar em terceira pessoa causa um efeito de sentido de objetividade, ou seja, como se os acontecimentos fossem narrados a si mesmos, mas gera em quem lê uma curiosidade, a busca pelo algo mais.

\footnotetext{
${ }^{2}$ A notícia, publicada no portal da rádio CBN, em 26 de maio de 2016, está disponível em http://cbn.globoradio.globo.com/rio-de-janeiro/2016/05/26/FAMILIA-QUERIAQUE-JOVEM-ESTUPRADA-FIZESSE-TRATAMENTO-PARA-DEPENDENCIAQUIMICA.htm. O conteúdo mescla texto e áudio, uma versatilidade disponível em mídias online. No entanto, foi analisada apenas a versão escrita. Essa notícia é fonte de informação para a Notícia 2, do portal do jornal 0 Globo.
} 
No enunciado, apresentado na editoria "Rio de Janeiro", é possível identificar a voz da família da jovem, na clara presença do discurso indireto. São os familiares que revelam o desejo de tê-la internado para tratar de dependência química. Se o discurso indireto marca uma pretensa objetividade, como identificar a responsividade, ou as várias vozes, característica da própria linguagem? Que outras vozes estão inseridas nessa notícia, e mais especificamente marcadas no título?

A família, mais especificamente a avó, responde a uma voz social que condena o comportamento da menina, tentando justificar o porquê de a neta ter se envolvido nessa situação. Para a família, a jovem, por ser viciada, precisaria de ajuda, de tratamento.

No subtítulo, ao enunciar que a menina precisa de tratamento médico, a família busca adesão dos leitores, apresentando-a como vítima. Tanto que a avó diz que a neta "tem coleguinhas, mas na hora nenhum apareceu para ajudar", que é marcado no texto pelo discurso direto. Ou seja, há uma vitimização da jovem, como pode ser verificado abaixo.

A avó dela, que não quis se identificar, disse que ela engravidou aos 13 anos e que 'tem coleguinhas na favela, mas na hora nenhum apareceu para ajudar'. Mais de 30 homens cometeram o estupro coletivo da menina (CBN, 2016 [grifo nosso]).

Porém, em outro viés de leitura possível, há uma voz social que condena aquele que se droga. Nessa perspectiva, o drogado não é alguém doente que precisa de ajuda, mas é um malandro ou criminoso, merecedor do que com ele ocorre. Assim, ao selecionar uma das informações fornecidas pela avó - de que a menina engravidou aos 13 anos -, há o reforço de uma voz coletiva que vê o viciado como um problema, sendo assim, o princípio da responsividade se manifesta.

No jogo polifônico, a voz da avó é marcada pelo discurso direto e indireto, mas ressalta-se que, acima de tudo, há um diálogo com outras vozes, e é nesse espaço que o discurso se constitui. 
V. 8 (2)

80-99

mai/ago 2018

Notícia $2^{3}$

"Quando acordei tinha 33 caras em cima de mim", diz menina que sofreu estupro coletivo (O Globo, 2016 [grifo nosso]).

Nesse título, a voz em primeira pessoa é marcada por meio do uso de aspas, ou seja, é explícita, o que traz dramaticidade à narrativa já que inicia com um trecho do depoimento da vítima de estupro. A escolha lexical "menina" reforça a ideia de fragilidade e medo da vítima, gerando indignação a quem lê. Na voz da vítima, apenas uma menina no ponto de vista do jornalista, ressoam as vozes de outras tantas mulheres que sofreram ou sofrem abuso. A voz marcada da menina dialoga com uma outra voz social que condena qualquer violência contra mulheres, que é contra o feminicídio e que, portanto, solidariza-se com o fato ocorrido. Por essa leitura, há uma tentativa marcada de solidariedade para com aquela que sofreu abuso.

Para Bakhtin (1997, p. 159-160), o discurso direto admite elementos emocionais e afetivos, como abreviações e elipses, ou, como ele mesmo destaca, "expressões muito coloridas" em que se difunde o real significado e a maneira de falar da personagem/fonte. Ainda de acordo com o filósofo, o uso das aspas assegura uma forma diferente de leitura: um distanciamento é gerado pelo narrador, que lê o discurso direto como uma fala dita por alguém. Porém, cabe novamente ressaltar que a linguagem não é neutra e que a escolha desse dizer e dessa forma de dizer "tinha 33 caras em cima de mim", revela, mesmo que de forma implícita, uma orientação argumentativa.

Na análise da notícia, encontrada na editoria "Rio", cabe destacar que, logo no primeiro parágrafo, o jornalista Guilherme Ramalho trata a menina como vítima e os acusados como criminosos. Aqui, verifica-se ainda que O Globo é o único dos cinco veículos analisados que tem a matéria assinada por um jornalista, enquanto que nos demais é assinado apenas "redação" ou nem mesmo consta outra informação além de "atualizada".

A menina de 16 anos que foi vítima de um estupro coletivo em uma comunidade da Zona Oeste [...] A polícia já identificou quatro dos criminosos (O Globo, 2016 [grifo nosso]).

\footnotetext{
3 A notícia, publicada no portal do jornal O Globo, em 26 de maio de 2016, está disponível em http://oglobo.globo.com/rio/quando-acordei-tinha-33-caras-emcima-de-mim-diz-menina-que-sofreu-estupro-coletivo-19380492. Essa notícia é fonte de informação para a Notícia 3, no portal do jornal Diário do Nordeste.
} 
Chama a atenção a grande quantidade de vozes presentes nessa narrativa: além da própria menina, encontram-se o pai da menina, a avó da menina, a voz do Ministério Público e dos presidentes da Comissão de Direitos Humanos da Assembleia Legislativa e da Câmara de Vereadores do Rio de Janeiro. A questão geográfica é um diferencial a ser analisado, já que o veículo de comunicação está localizado na cidade em que ocorreu o estupro. O emprego de todas essas vozes reforça a leitura de que a menina é uma vítima e ecoa uma voz social que não admite que uma pessoa, no caso específico do sexo feminino, sofra esse tipo de agressão. A seguir, alguns extratos das diferentes vozes que nada mais fazem do que balizar a voz social de que o estupro é inadmissível.

- Quando acordei tinha 33 caras em cima de mim - disse a menina, que tentou diversas vezes fugir do hospital - Só quero ir para casa.

Aos choros, o pai da menina, que pediu para não ser identificado, disse que ela teria ido a um baile funk no Morro São José Operário, em Praça Seca, na última sexta-feira.

- Ela foi num baile, prenderam ela lá e fizeram essa covardia. Bagunçaram minha filha. Quase mataram ela. Estava gemendo de dor. Ficou tão traumatizada que só conseguia chorar.

A avó da vítima, em entrevista à rádio $\mathrm{CBN}$, disse que ela teria sofrido um apagão durante os abusos.

- O vídeo é chocante, eu assisti. Ela está completamente desligada. Ela tem umas coleguinhas lá, mas nessa hora nenhuma apareceu. Eles, inclusive, postaram diversos comentários a respeito, todos eles irônicos. (O Globo, 2016 [grifo nosso]).

A voz de uma entidade reforça, positivamente, o sentimento dos pais, dando o respaldo de ver a menina como uma vítima. O presidente da Comissão de Direitos Humanos da Assembleia Legislativa do Rio de Janeiro é ouvido.

O deputado Marcelo Freixo (PSOL), presidente da Comissão de Direitos Humanos da Assembleia Legislativa do Rio de Janeiro (Alerj), está acompanhando o caso da menina, que só reapareceu nesta quarta-feira.

- A comissão vai acompanhar o caso para garantir todo o 
V. $8(2)$

80-99

mai/ago 2018

atendimento à menina. Ontem (quarta-feira), a acompanhamos para fazer o exame de corpo de delito. Tentamos falar com ela, mas está muito abalada e sem condições de falar. Vamos garantir que ela tenha acompanhamento psicológico - disse o deputado (O Globo, 2016 [grifo nosso]).

O emprego do verbo "garantir" revela o nível de adesão dessa entidade à voz social de que abuso é crime e que as pessoas que sofrem esse ato precisam de ajuda, sem restrições.

Notícia $3^{4}$

"Quase mataram ela", disse pai da jovem de 16 anos que sofreu estupro coletivo no Rio de Janeiro (Diário do Nordeste, 2016 [grifo nosso]).

Novamente a presença do discurso direto no título explicita a voz daquele que fala, deixando o jornalista numa posição pretensamente neutra. Tanto que ao optar por trazer como título a voz do pai, podese levantar a hipótese da existência de um diálogo com uma outra voz social, a voz masculina. Nesse momento, essa voz se contrapõe a discursos machistas, ao condenar um ato feito por seus pares, homens.

O jomalista se utiliza do emprego da voz do pai em citação direta também para estabelecer um possível diálogo com as vozes de incredulidade frente a um estupro coletivo cometido por 33 homens. Pela voz do pai, apagamse as vozes que se perguntam se a menina poderia sobreviver ao ato e, por meio dele, está a voz da filha que relata ter sido estuprada por 33 homens. O pai, assim, garante o dizer da filha, pois, no jogo de vozes existentes, ele é o pai, portanto, o seu discurso pode ter maior valor do que o da própria filha, que é mulher e, assim, pode ser uma voz estigmatizada. Com isso, o jomalista, ao selecionar tal fala para o título, tensiona vozes sociais que reverberam.

É importante salientar que a polifonia não se resume apenas às fontes relacionadas no texto, mas, principalmente, às vozes que aceitam ou refutam a informação apresentada, ou seja, as vozes sociais motivadas pela interação, que fazem sua interpretação da notícia.

\footnotetext{
${ }_{4}^{4}$ A notícia publicada no portal do jornal Diário do Nordeste, em 26 de maio de 2016, está disponível em http://diariodonordeste.verdesmares.com.br/cadernos/nacional/ online/quase-mataram-ela-disse-pai-da-jovem-de-16-anos-que-sofreu-estuprocoletivo-no-rio-de-janeiro-1.1556255. Essa notícia utiliza informações dos portais da rádio CNB e do jornal O Globo.
} 
Na sequência da notícia, fica explícito o dialogismo não apenas pelas vozes da vítima e dos familiares, mas pelo uso de outros veículos de comunicação.

Ao sair do local, em entrevista ao jornal "O Globo", ela falou sobre o ocorrido.

A avó da vítima concedeu entrevista à rádio $C B N$ e disse que assistiu ao vídeo postado no Twitter na terça-feira (22) (Diário do Nordeste, 2016 [grifo nosso]).

No entanto, essa questão não impede que o veículo apresente seu ponto de vista, com a edição/seleção do conteúdo original, sendo que a notícia consta na editoria "Nacional". Ressalta-se que esse foi o único veículo de comunicação que apresentou o pai da vítima como porta-voz principal no caso do estupro e parte da entrevista foi extraída e inserida no título, como analisado anteriormente.

Ela foi num baile, prenderam ela lá e fizeram essa covardia. Bagunçaram minha filha. Quase mataram ela. Estava gemendo de dor. Ficou tão traumatizada que só conseguia chorar (Diário do Nordeste, 2016 [grifo nosso]).

A voz masculina dialoga com todas as outras vozes masculinas, reprovando esse tipo de ato. Ao mesmo tempo, situa-se ao lado das muitas vozes femininas que cotidianamente sofrem com abusos dessa natureza. Enfim, uma voz masculina, e nordestina, solidariza-se com vozes femininas. Há de se pensar o quanto essa seleção realizada pelo jornalista seria aleatória. Fiorin aponta que uma palavra isolada não permite uma resposta, entretanto, quando inserida em um enunciado admite uma resposta. "As unidades da língua não são neutras, enquanto os enunciados carregam emoções, juízos de valor, paixões [...]" (FIORIN, 2016, p. 26). 
V. 8 (2)

80-99

mai/ago 2018

Notícia $4^{5}$

Polícia tenta identificar bandidos que praticaram estupro coletivo em favela do Rio de Janeiro (Veja.com, 2016 [grifo nosso]).

O uso de terceira pessoa também é característico nesse título e, mais uma vez, constata-se o discurso indireto. Porém, é possível identificar uma outra voz, a do querer justiça, em especial por meio do uso da oposição entre duas palavras: bandido e polícia.

Há eco de uma voz social que quer justiça, e mais, nesse eco, quem pode atender a esse pedido é a polícia que "tenta identificar", ou seja, ela está atuante. O emprego de antônimos, como bandido e mocinho, é carregado ideologicamente. É a polícia que defende a sociedade civil, é ela que pode promover a justiça. Enquanto isso, aqueles que praticaram o estupro já são julgados, o que é marcado pela palavra "bandidos" e não estupradores.

Em Marxismo e filosofia da linguagem, Bakhtin aponta que "Na realidade, não são palavras o que pronunciamos ou escutamos, mas verdades ou mentiras, coisas boas ou más, importantes ou triviais, agradáveis ou desagradáveis, etc. A palavra está sempre carregada de um conteúdo ou de um sentido ideológico ou vivencial" (1997, p. 95, grifo do autor).

Tanto é verdade que as vozes são ideologicamente marcadas que, no lead, primeiro parágrafo da notícia, o jornalista marca seu ponto de vista ao descrever fatos que não presenciou, mas cuja gravação, postada pelos suspeitos que cometeram o abuso, propagou-se nas redes sociais.

A cena de barbárie chocou as redes sociais. De várias partes do Brasil, cidadãos começaram a entupir as caixas de mensagem da Ouvidoria do Ministério Público e da Delegacia de Repressão aos Crimes de Informática (DRCI) do Rio de Janeiro para denunciar os agressores e pedir providências (Veja.com, 2016 [grifo nosso]).

A adjetivação já tonaliza o posicionamento da própria Veja, ao utilizar as palavras "barbárie", "chocou", "denunciar os agressores".

${ }^{5}$ A notícia, publicada no portal da revista Veja, em 26 de maio de 2016, está disponível em http://veja.abril.com.br/brasil/policia-tenta-identificar-bandidos-que-praticaramestupro-coletivo-em-favela-do-rio-de-janeiro/. 
Não é sobre um estupro de que se fala, mas sim sobre a cultura do estupro. A voz que inicialmente se sobressai é a de um coletivo que não admite tal violência quando o veículo diz "De várias partes do Brasil [...]". Mais ainda, à voz da Veja junta-se a voz de "cidadãos". Reforçase um padrão de comportamento, a voz coletiva do que é correto, e a Veja junta-se a esse padrão.

A força ilocucional ${ }^{6}$ do primeiro parágrafo, de certa forma, apaga alguns tensionamentos que aparecem no segundo parágrafo, em que o leitor toma conhecimento de que a adolescente namorava um suspeito de integrar o tráfico, além de ser inserida a informação de que ela já é mãe e frequentava bailes funks. Também se drogava e parece ser usual o fato de ela não voltar para casa aos finais de semana. Há um perfil negativo construído, mas que pode não ter força suficiente para apagar o que anteriormente foi posto no primeiro parágrafo.

C.B.T.P. namorava um homem suspeito de integrar o tráfico da favela, identificado apenas pelo apelido de Petão, e que estudava com ela numa escola do bairro da Taquara. Na madrugada do último sábado, dia 21, ela saiu da casa onde morava com a mãe e o filho de 3 anos para ir a um baile funk na favela. Só retornou dois dias mais tarde, segundo a família visivelmente drogada e com roupas masculinas, já que as suas haviam sido roubadas: "Ela foi tomar um banho e dormiu", disse a mãe em depoimento. A.T. contou também que procurou o Conselho Tutelar para tentar internar a filha compulsoriamente após o ataque (Veja.com, 2016 [grifo nosso]).

A voz de um dos investigadores, no terceiro parágrafo, faz eco às vozes de indignação, que solicitam justiça, "pedindo providências", como apontado no primeiro parágrafo.

'Quando ela acordou na favela, tinha mais de 30 traficantes em volta rindo e zombando' contou um investigador ao site de VEJA (Veja.com, 2016 [grifo nosso]).

\footnotetext{
${ }^{6}$ Uma das dimensões propostas pelo filósofo da linguagem Austin na sua Teoria dos Atos de Fala. Tal teoria foi posteriormente desenvolvida por Searle. Para Austin, o dizer é fazer e ação e envolve três dimensões, (a locutória, ilocutória e perlocutória). A força ilocutória associa-se à produção de efeitos de sentidos de um dado dizer. $\mathrm{O}$ ato ilocucional está associado com a produção de efeitos por meio do informar, ordenar, prevenir, avisar, ou seja, é aquilo que faz com que tal enunciado realize um ato (AUSTIN, 1990).
} 
V. $8(2)$

80-99

mai/ago 2018

É uma voz masculina, e de um investigador, que reforça o dizer da adolescente que sofreu abuso, ou seja, qualquer marca negativa é supostamente apagada, para se dar destaque ao fato em si, e não à pessoa que sofreu o ataque. Por fim, constata-se que o conteúdo apresentado está na editoria "Brasil".

Notícia $5^{7}$

Vítima de estupro no Rio foi dopada e diz ter visto 33 homens ao acordar (ZH, 2016 [grifo nosso]).

Verifica-se no título, mais uma vez, a pretensa neutralidade com a utilização da terceira pessoa. Entretanto, aqui, as escolhas lexicais reverberam diferentes vozes de uma forma distinta. No enunciado acima, verifica-se que o jornalista utiliza o recurso da terceira pessoa, além disso, é possível identificar um período composto formado por duas orações unidas pelo "e", sendo que na segunda oração é utilizado o verbo dicente "diz", para dar voz à vítima.

Quando se trata de oração, Bakhtin (2011, p. 283) defende que "Aprender a falar significa aprender a construir enunciados (porque falamos por enunciados e não por orações isoladas e, evidentemente, não por palavras isoladas)". E o enunciado construído no título já permite ao leitor duvidar do que ocorreu. Se a vítima "foi dopada", entende-se, no coletivo, que quem está dopado não tem condições de presenciar algo e, dentro dessa visão, não tem autoridade para dizer o que diz. Tanto que o que segue, apresentado em discurso indireto, também modaliza o dizer "diz ter visto". Fica ao leitor a dúvida: será que realmente havia 33 homens no recinto?

Esse questionamento dialoga com tantas outras vozes que, em diferentes meios, questionaram a veracidade do ocorrido. A ZH, assim, reforça essa voz de desconfiança que surgiu no coletivo.

No desenrolar da notícia, a jovem admitiu à polícia ser usuária de drogas, dando voz a uma suposta admissão de culpa pela condição em que se encontra. No entanto, em seguida, é inserida a informação de que ela estaria "há um mês sem usar", o que induz à dúvida quanto à real situação em que ela se encontrava no momento do estupro: dopada ou drogada?

\footnotetext{
${ }^{7}$ A notícia, publicada no portal ZH, do jornal Zero Hora, em 26 de maio de 2016, está disponível em http://zh.clicrbs.com.br/rs/noticias/policia/noticia/2016/05/vitimade-estupro-no-rio-foi-dopada-e-diz-ter-visto-33-homens-ao-acordar-5810880. html. Essa notícia utiliza informações do portal da revista Veja.
} 
À polícia, ela admitiu ser usuária de ecstasye cheirinho da loló, mas disse não ter consumido nada na noite das agressões, pois estaria há um mês sem usar as substâncias (ZH, 2016 [grifo nosso]).

Apesar do ceticismo criado, a notícia traz vozes que apontam para a gravidade do fato, de que militantes feministas levaram o caso para o Ministério Público do Estado do Rio de Janeiro, e a notícia destaca que a Safernet solicita que as imagens não sejam compartilhadas. Ou seja, nas vozes que ressoam, marca-se a voz de que não há lugar para a cultura do estupro. Por fim, não menos importante, constata-se que a $Z H$ é o único veículo dos cinco analisados que explicita a notícia como um caso de polícia, ao inseri-la nessa editoria.

\section{Considerações finais}

A análise de notícias sobre o estupro coletivo no Rio de Janeiro, apresentada neste artigo, reforça a ideia que a linguagem é dinâmica e mutável, cujos efeitos de sentidos são diversos e se apresentam pelo dialogismo.

Inevitavelmente, fios ideológicos perpassam os dizeres. As escolhas lexicais e linguísticas, as escolhas tipológicas e até tipográficas sempre estão a serviço de produção de sentidos. Para tão somente reforçar o já dito, a personagem da notícia é tratada por "menina", "jovem", "adolescente", drogada", "viciada" "mãe aos 13", além de haver também o acréscimo ou seleção de uma declaração e não de uma outra, como ficou evidente no caso da voz explícita do pai em um título. Os recursos recortados da língua deixam clara a visão de mundo do jornalista na produção da notícia, visto que tal gênero tem como característica o relato de uma série de fatos selecionados pelo prisma do profissional.

Neste artigo, verifica-se que a mídia eletrônica, espaço relativamente novo de propagação da informação, garante ainda mais agilidade às notícias e a possibilidade de veículos diretos serem utilizados por outros veículos como fontes, restringindo a necessidade dos meios indiretos, as agências de notícias.

Dessa forma, verifica-se que as notícias analisadas são dialógicas, revelando uma multiplicidade e independência de vozes e permitindo a interação com o leitor. Tudo isso se dá a partir da enunciação jornalística. As vozes dos entrevistados são selecionadas, evidenciadas, 
V. $8(2)$

80-99

mai/ago 2018

suprimidas pela enunciação jornalística, que lhes dá relevo, cor ou ausência. Há, assim, uma mistura de vozes dos entrevistados com a enunciação jornalística. Assim, nenhuma escolha é vã. Fios ideológicos, mais ou menos marcados, tecem as tramas narrativas que são lidas todos os dias por milhares de internautas. O quanto essas tramas evocam vozes sociais dissonantes ou consonantes às ideias do próprio leitor é que fazem a notícia ser bem ou mal recebida, encontrando eco nas vozes que ressoam no próprio leitor. O discurso permite refletir a posição e a ideologia na relação do eu com o outro.

\section{Referências}

AUSTIN, John Langshaw. Quando dizer é fazer. Trad. Danilo Marcondes de Souza Filho. Porto Alegre: Artes Médicas, 1990.

BAKHTIN, Mikhail. Marxismo e filosofia da linguagem: problemas fundamentais do método sociológico na ciência da linguagem. 8. ed. São Paulo: Hucitec, 1997.

BAKHTIN, Mikhail. Estética da criação verbal. 6. ed. São Paulo: WMF Martins Fontes, 2011.

BEZERRA, Paulo. Polifonia. In: BRAIT, Beth (Org). Bakhtin: conceitos-chave. São Paulo: Contexto, 2005.

ERBOLATO, Mário L. Técnicas de codificação em jornalismo: redação, captação e edição no jornal diário. 5. ed. São Paulo: Ática, 1991.

FIORIN, José Luiz. Introdução ao pensamento de Bakhtin. 2. ed. São Paulo: Contexto, 2016.

LAGE, Nilson. Linguagem jornalística. 5. ed. São Paulo: Ática, 1997.

LAGE, Nilson. Ideologia e técnica da notícia. 3. ed. Florianópolis: Insular, 2001.

LAGE, Nilson. Estrutura da notícia. 6. ed. São Paulo: Ática, 2006.

MACHADO, Irene. Digitalização. Linguagem. Discurso. As mediações dialógicas possíveis. Lumina. Juiz de Fora - Facom/UFJF. v. 4, n. 2. p. 19-48, jul/dez 2001.

ONU: Taxa de feminicídios no Brasil é quinta maior do mundo; diretrizes nacionais buscam solução. ONUBR Nações Unidas do Brasil. 12. abr. 2016. Disponível em: <https://nacoesunidas.org/onu-feminicidio-brasil-quintomaior-mundo-diretrizes-nacionais-buscam-solucao/>. Acesso em: 06. ago. 2017.

PETTER, Margarida. Linguagem, língua, linguística. In: FIORIN, José. (Org). Introdução à Linguística I: Objetos teóricos. 6. ed. Revista e atualizada. São Paulo: Contexto, 2010. 
ROSSI, Clóvis. O que é jornalismo. 10. ed. São Paulo: Brasiliense S.A, 1994.

SAUSSURE, Ferdinand de. Curso de Linguística Geral. Organização Charles Bally e Albert Sechehaye; com a colaboração de Albert Riedlinger; prefácio à edição brasileira de: Isaac Nicolau Salum [tradução Antônio Chelini, José Paulo Paes, Izidoro Blikstein]. 28. ed. São Paulo: Cultrix, 2012.

TEZZA, Cristovão. Discurso poético e discurso romanesco na teoria de Bakhtin. In: FARACO, Carlos Alberto et al. Uma introdução a Bakhtin. Curitiba: Hatier, 1988. 